\title{
Toward a Sound National Program in Cataloging
}

Dr. Ruffin is librarian, State Teachers College, Farmville, Va.

IN CURRENT library literature, reference $^{\mathrm{N}}$ is made to three phases of cataloging history: The period which precedes the turn of the nineteenth century; the middle period, embracing the first four decades of the twentieth century; and the period since I94I.

\section{The Early Period:}

\section{The Librarian as Cataloger}

The early period falls roughly into two parts: A pioneer period, extending to 1876 , when institutional practices were in the process of a slow evolution, and the period from 1876 to 1908 , during which time everything in the profession, including cataloging techniques, was being organized and codified for the mutual benefit of practicing librarians. This period was so full of vitality, so overflowing with conflicting ideas, so realistic in its approach to ideas greatly conceived and executed that it has been labeled the romantic age in the history of American librarianship.

In both the pioneer period and this romantic period we find the library administrator as cataloger. In the earlier period the listing of books was a minor activity in this librarian's daily routine. It represented a means to the accomplishment of some library objective. At Harvard the

${ }^{1}$ Paper presented at the Workshop for College and University Librarians, School of Library Science, University of North Carolina, July 28, 1948. first catalog, published in 1723 , was for the purpose of acquainting certain prospective donors in London with the book holdings in the infant college in the colony of Massachusetts. The primary object of this catalog was the acquisition of books. At Yale the first catalog, dated 1745 , was compiled because the new head of the college saw "that the students were deprived of much benefit and advantage of the library, for want of a proper catalogue of books." This catalog was dedicated "To the students of Yale College," so that they might "readily know and find any book, upon any particular subject." The sole object of this catalog was to meet the needs of the college student.

By 1876 librarians had developed a lively interest in cataloging. The activities of the newly organized American Library Association centered on such technical subjects as the analytic indexing of periodical literature, the classification of books in libraries, the relative merits of book and card catalogs, and the perfecting of Cutter's Rules for a Dictionary Catalog. Under the impetus of the new movement, administrative heads became expert technicians. Cataloging had emerged not only as a major activity in librarianship, but was a major field of emphasis in the professional activities of the library administrative heads.

Soon after the turn of the century, this constructive phase in the history of cataloging reached its peak. Cutter's Rules had gone through four editions; and the Ameri- 
can Library Association had published its Catalog Rules and List of Subject Headings. Centralized cataloging at the $\mathrm{Li}$ brary of Congress was underway, and the classification schedules and the standardized subject headings used in this national institution were becoming accessible to libraries throughout the country. Administrative heads assumed less and less responsibility for the cataloging activity of their libraries, many of which by this time had become functionally organized. In the words of Charles A. Cutter, the golden age of cataloging with its challenging difficulties and exhilarating discussions was over, and a great change was to come upon the status of cataloging in the United States. ${ }^{2}$ Cutter's prophecy came true. The printed codes on the techniques of cataloging, which had been produced since 1876 , brought about a demand for a body of specialists, skilled in the manipulation of these techniques. The burden of the cataloging activity was assigned to these specialists, and the narrow concept of cataloging as the process of preparing entries for a card cata$\log$ slowly crystallized.

Since such importance thus became attached to catalog entries for books, it is only right that we should have some knowledge of their technical evolution. Before I 876 we find that the character of cataloging was peculiar to individual institutions. The early history of cataloging was therefore a history of local developments. The compiler of a book catalog was free to choose his own set of rules. Individuality in catalog entries thus held its own against the day of catalog codes, and uniformity had yet to be achieved.

In their early manifestations cataloging techniques were crude and rough, but they were plastic. Evolution was thus possible.

\footnotetext{
${ }^{2}$ Cutter, Charles A. Rules for a Dictionary Catalog. U.S. Bureau of Education, Special Report on Public Librarics, Part II (4th ed., rewritten) Washington, U.S. Government Printing Office, 1904, p. 3 .
}

The instrument through which their development can be traced is the printed book catalog. In a study of the early book catalogs of Harvard and Yale the writer traced a series of representative catalog entries through 150 years of parallel development in cataloging techniques. ${ }^{3}$ These entries were checked insofar as possible in consecutive catalogs for fullness of entry as to author's name, title, imprint and physical description. Added entries (including subject entries), as well as related cross references, were also considered. The entry for Plutarch's Lives, for example, was traced through 66 college and society catalogs, dating from 1723 to 1873 . The data resulting from such a study give evidence to the historical evolution of cataloging theory. A definite body of principles had emerged by 1876 , and a demand for specific and uniform rules followed.

In answer to this demand the British Museum had published as early as I84I, along with its Catalogue of Printed Books, its Rules for the Compilation of the Catalogue. ${ }^{4}$ These rules came into print again in 1866 . They continued, however, to be local in their purpose and in their application.

In the meantime, in 1853 , Charles C. Jewett, librarian of the Smithsonian Institution, published his report $\mathrm{On}$ the Construction of Catalogues of Libraries. ${ }^{5} \mathrm{Al}-$ though based on the practices in use at the Smithsonian Institution, this manual had the distinction of being published for the express purpose of assisting librarians in the compiling of printed catalogs. The

\footnotetext{
${ }^{3}$ Ruffin, Beverley. "Some Developments towards Modern Cataloging Practice in University Libraries as Exemplified in the Printed Book Catalogs of Harvard and Yale before the Year 1876," Unpublished Master's Thesis, School of Library Service, Columbia University, 1935 .

versity, ${ }^{1} 935$. logue of Printed Books in the British Museum. v. I, I 841 , p. v-ix.

Jewett, Charles C. On the Construction of Cata. logues of Libraries. $2 \mathrm{~d}$ ed., 1853 . The first edition, printed in 1852 , was limited to a few copies which were distributed among those likely to suggest improvements.
} 
science of cataloging was thus groping toward uniformity on a national scale. The complete divorce from the institutional point of view came about in 1876 with the publication of Cutter's Rules for a Printed Dictionary Catalog. In his preface Mr. Cutter presents this publication as a first attempt to investigate the principles of cataloging and to set forth the rules in a systematic way. Thus our so-called theory of cataloging was born, and put into use by means of "settled rules of action." Even so, the leaders in the profession for yet another quarter-century centered their major attention on the perfecting of cataloging rules and other techniques having to do with the cataloging and classification of books. These efforts culminated in 1908 in the publication of the A.L.A.'s Catalog Rules.

\section{The Middle Period, 1908-194I: \\ The Technical Specialist as Cataloger}

If the golden age of cataloging was over by the turn of the century, what took place from that time until the beginning of the I940's? What happened in the first four decades of the present century? What implications lie in the fact that this middle period was ushered in with the publishing of the first edition of the A.L.A.'s Catalog Rules, and that it was set for a knockout blow coincident with the appearance of the second edition of these same cataloging rules? Answers to such questions can be found only if one is familiar with the characteristics of the era under discussion. What are these characteristics? Attention may be called to three which are deemed to be of primary importance.

We shall note first that this middle era was a period of productivity in cataloging. Bibliographical machinery for the proper cataloging of books had been set up for action by 1908 . Full time specialists directed by master technicians were put to work. Department heads organized the routine of their operations. Card catalogs resulted: trays of cards, cabinets of trays, and acres of catalog cabinets. Duplicate card catalogs appeared: official, for the use of the staff; departmental, for the convenience of seminar groups; union, to show different institutional holdings. The millions of catalog cards, which were being processed by typewriters, by varied kinds of mimeographing equipment and by printing presses, were also the sources of information for shelves of printed catalogs, indexes and bibliographies.

The A.L.A.'s Catalog Rules had to be supplemented by codes for the cataloging of periodicals and for serials. Codes were issued for music and for maps. L. C. classification schedules multiplied. The Dewey decimal system changed its mathematical symmetry to ragged outlines resembling those of a giant amoeba. Lists of subject headings also multiplied: supplements to those used at the Library of Congress; new editions of the same; a subject heading list for pedagogical materials, another for chemistry, and still another for physics-all striving to keep up with the jargon of a fast moving social and academic milieu.

Unable to discard its obsolete parts and staggering under increased size and weight, card catalogs nevertheless have rendered a remarkable service. These catalogs, varying in size from a single tray to hundreds of cabinets, are evidence that productivity was a marked characteristic of this period.

Classicism was a second characteristic of this period. It was Andrew H. Osborn who first applied this term to cataloging. By classicism Dr. Osborn means that the making of card catalogs was regulated by a body of technical rules. Simplicity in the application of these rules seemingly gave way to elaborate and highly compli- 
cated technical procedures. Therein lies the danger. Yet it has been said that, insofar as cataloging is concerned, every rule grew out of a definite need, either brought forward by the users of the catalog or else inherent in the complex character of the processing machinery. Be that as it may, it might well be agreed that only by adherence to uniform rules for cataloging well-defined types of materials was the mass production of catalog records made possible during those 40 years. Mass production of any sort rarely takes place without sacrificing quality; it also does not cater to individual tastes or needs. It was the mass production of L.C. cards, therefore, with their apparently needless elaboration of technical detail, that brought on a storm of protest. Jewett's program for a national standard had overshot the mark. As a consequence the interests of the individual institution were obscured and neglected.

There were other destructive forces at work. In institutions where authority had been placed above reason, decadence had set in. Such a condition inevitably stifled the professional growth of the individual cataloger. Protest against an authority based on prestige rather than on ability and sound judgment often took the form of inertia, with morale dropping to a low ebb. Destructive elements obtaining from such situations can hardly be gauged solely from the evidence found on catalog cards. The results were far more detrimental in their total effect.

Decadence also resulted from a management which was divorced from administration. By this I mean that the manager of the catalog department, i.e. the head of the department, was not in a true sense an administrative officer in the library. The head of the department was a catalog librarian, not an assistant librarian. $\mathrm{He}$, or she, was delegated to look inward at the cataloging processes. The welfare of the library, with its social implications, was other people's business. Thus the catalog librarian's allegiance was fostered on the department rather than attached to the library as a whole. There was little chance to discuss library policies and less chance to act on them. There was no contact with governing officials over and above the head librarian, whose position thus took the form of a complete bottleneck between two groups. The department head was forced to view his product from the inside. Having more often than not come up from the ranks as a technician, he took on the activities of a manager without the privileges and attributes of an administrative officer. Such an organizational pattern increased the dangers inherent in an age of classicism.

A third major characteristic of the period from 1908 to $194 \mathrm{I}$ was an excess of raw material. Cataloging machinery could not absorb the unforeseen avalanche of material on hand to be processed. In his "Memoranda on Library Cooperation," Herbert A. Kellar spoke of this material as a tidal wave which threatened to inundate the library world. ${ }^{6} \quad \mathrm{He}$ noted that almost 500,000 items, excluding manuscript, were received in 1940 at the Library of Congress. This institution, according to a report made by Lucile Morsch in $194 \mathrm{I}$, was cataloging at a rate of 53,000 titles a year. ${ }^{\tau}$ An annual arrearage of 30,000 , reported for this library at that time seems an understatement in the face of such figures. In other research libraries of the country, the situation at the Library of Congress was more or less duplicated. The impact resulting from such conditions affected the tempo in libraries of every sort. The crisis in cataloging had arrived.

\footnotetext{
"Kellar, Herbert A. "Memoranda on Library Cooperation," no. I (September 1941). Washington, D.C." The Library of Congress, 1941. (Mimeographed.)

7 Morsch, Lucile. "Simplified Cataloging," in Catalogers' and Classifiers' Yearbook, no. Io. Chicago, American Library Association, 1944, p. 25-32.
} 
The Renaissance in Cataloging History, I94I-

Thus we see that at the end of four decades of intensive activity, librarians suffered their first great defeat in their effort to supply a complete catalog record for all printed materials of nationally recognized importance. Whose was the blame? Of the large functional groups within the profession, the catalogers, in the very wealth of their handiwork, had supplied the most concrete source of evidence for examination as to work effectiveness. With the critical eye of the profession already ferreting out case after case in which catalogers had shown a lack of judgment in the making of catalog cards, a veritable storm of protest against the rules themselves broke loose with the publication in I94I of the new edition of the A.L.A. Catalog Rules. This storm had long been gathering. Indeed it was pretty well under way by 194I. The battle cry was sounded by Dr. Osborn in his description of the "Crisis in Cataloging," ${ }^{\prime}$ and the publication of the new rules simply marks the turning point in a controversy in which catalogers caught the blame. Catalogers, before and after this turning point, faced a barrage of destructive criticism largely from administrative officers and other noncataloging librarians, few of whom acknowledged any share of responsibility for the impending crisis. Not only was the cataloger as a person isolated and stigmatized, but the catalog itself was ridiculed and avoided. In the discussions which appeared in print, the inevitable foibles of classicism were exposed. The cataloger's attempts to defend his position often revealed his narrowed point of view and showed his curtailed powers in setting up the very cataloging policies for which he was being held responsible.

More recently a phase of constructive

8 Osborn, Andrew D. "The Crisis in Cataloging." Library Quarterly 11:393.411, October 1941. criticism has predominated the scene. Administrative and reference librarians are admitting a share of the responsibility for the crisis. Catalogers themselves have engaged in an analysis of their procedures in an effort to sift the wheat from the chaff. One notable effort of this type is Julia Pettee's article in the Catalogers' and Classifiers' Yearbook for 1945, in which she considers the basic principles of our author catalogs. ${ }^{9}$ Here she points out instances where simplification, rather than complexity, has been achieved. An example in case is the use of rules governing the assembling of all variants of a literary unit under the responsible personal or corporate author. Miss Pettee evaluates cataloging rules in order to estimate their worth rather than to find evidence of decay. She offers up her findings for continued use in the cataloging of books, rather than as defense machinations in a professional warfare.

In the field of administration, proposals for the reorganization of catalog departments have ranged from the combination of order and catalog department, now an accomplished fact in many libraries, to the complete elimination of the catalog department in libraries, with the idea of turning over the descriptive cataloging to the order department and the subject cataloging to the reference department. Such radical proposals as this latter one serve at least to arouse healthy, if heated, discussions of cataloging, which we must remember has in recent years been designated the profession's number one problem.

Destructive criticism brought forth defense measures. Constructive criticism is being translated into action. A renaissance, breaking through the bonds of classicism, has caused a resurgence of ideas which are revitalizing old techniques and creating

? Pettee, Julia: "The New Code: a Consideration of Basic Principles of Our Author Catalogs," in Catalogers' and Classifiers' Yearbook, no. II. Chicago, American Library Association, 1945, p. 7-19. 
new ones. The Library of Congress has taken a series of important steps which should result not only in a simplification of cataloging rules, but will insure a greater degree of good judgment in their application. Any improvements in standards made at this great cataloging center will be followed by libraries throughout the country, even as some of their not so wise practices have been followed in the past. On the other hand some institutions are breaking away from L. C. practices which are not applicable to their own situations, compromising on those common elements necessary in centralized and cooperative cataloging. Many small libraries have turned to the H. W. Wilson Company for unit cards more nearly suited to their needs.

Institutional purchasing in fields of specialization, and other cooperative programs, have placed certain controls on the acquisition of library materials, even if they have not directly affected the annual increase in arrearage. The unification of order and catalog departments under a single administrative head has succeeded in eliminating certain duplication of records and in making it possible to shift personnel from one section to another according to the pressure of work. This unification has also had some effect upon the character of materials accepted for processing. As a rule catalogers have had no control over items accepted for processing. It would seem that they would take advantage of the present situation to go on the offensive for a change. Their own position in the rank and file of librarians has made them exceptionally vulnerable to attack. With arrearages accumulating on their doorsteps, no other group is in a more strategic position to secure damaging evidence concerning the admittance of items which are physically unfit and bibliographically unsound.

With the unification of cataloging and order work under the charge of an assistant librarian, an administrative hierarchy, hitherto lacking, has been created. This administrative assistant-a partner in the firm, as it were-works with the librarian in the making of library policies, turning then to cataloging as one major means of furthering the objectives which he has helped to set up for the institution as a whole. Since, however, this administrative assistant is responsible to the librarian for a group of administrative units, of which cataloging is one, he must work in close harmony with the head of each unit. If he is to contribute vitally to the best interests of the library, he must not only have the attributes of an administrator but he must also be familiar with sound theory and practice in cataloging. For much of this, he can look to the department head, who is still to be a master technician with a knowledge of such technical organization and skills as have been developed to the present time. This head of the department will continue to supervise the work of trained catalogers who will handle the bulk of the material to be processed.

\section{Conclusion}

The revolt which broke loose in I94I has also concerned itself with the training of these catalogers. Indeed, the whole structure of education for librarianship is under revision. Fast moving changes are seen in library school catalogs and announcements. A wealth of ideas on library education is reflected in current library literature. Conferences on the subject gather in all parts of the country. At the Southern Conference on Library Education which took place in Atlanta in the spring of 1948 two alternative plans were considered: (I) whether to have one basic program suitable for the education of all beginning librarians; or (2) whether to have a curriculum (Continued on page 235) 
devices have, however, as their common denominator the above stated demand for removal. And it is this demand for removal that finally throws out, as impracticable, all mechanical methods of catalog card searching.

Let's take a specific example. You as a reference librarian are asked to ascertain if your library possesses a copy of Pennsylvania Genera of Permian Brachiopoda by one William Selzer. Which process for the answering of this question is the easier one? To do what you do now, i.e. to go to your ten million card catalog and to look in it, under the author entry, "Selzer, William," for a title beginning "Pennsylvania Genera?" Or to resort to a mechanical searching process, which means to take all of your catalog's ten million cards out of their ten thousand catalog drawers and to run them through a mechanical sorting machine (then putting them back into their drawers again) until finally the machine comes to that one "William Selzer" card that you are looking for, and is automatically thrown out for your inspection? The answer is obvious.

Not so obvious at first glance, however, are a host of additional collateral difficulties.
We must remember for one thing that a large library catalog is usually servicing not one card searcher but a dozen-or a hundred-searchers simultaneously. If each one of these hundred searchers is to be mechanically served, it is clear that not one but a hundred sorting machines are going to be required, working simultaneously to find for each patron the single card-or the two or three cards - that each one wants. But for each patron (with ten million cards to be gone through) the automatic searching process is clearly going to be a matter of hours, taking the handling time of dozens of library attendants, and creating an enormous confusion of cards and files simultaneously going through the machine searching routine.

Finally, fifth, what of the physical wear and tear on your cards if they are going to be run constantly through these sorting machines? Obviously this running through is going to involve a certain amount of card erosion.

All of which would seem to sum up to this: that mechanical card filing applied to library card catalogs sounds appealing, but as yet cannot be deemed a practicable proposition.

\section{National Program in Cataloging}

\section{(Continued from page 232)}

for each type of librarianship-school, public and college or university. ${ }^{10}$ Insofar as cataloging is concerned, are there not lessons to be learned from the past? Since Jewett's time have we not got rather far away from the institutional point of view? In the brief account here presented of certain phases of cataloging history, we have learned that the institutional point of view

10 "Southeastern Conference, on Library Education, eastern Library Association, 1948, p. 4. prevailed in the pioneer period of cataloging history, that it steadily lost ground after 1876 , and that since 1908 it has been overwhelmed by a national pattern in card production-a pattern which has been actually detrimental to the welfare of some institutions. In the present renaissance in cataloging history, we hope that the cataloging interests of all types of libraries will find an adequate niche in a sound national program. 